\title{
PROSTAGLANDIN F IN THE UTERINE HORNS OF MICE WITH INTRAUTERINE DEVICES
}

\author{
I. F. LAU, S. K. SAKSENA AND M. C. CHANG \\ Worcester Foundation for Experimental Biology, \\ Shrewesbury, Massachusetts 01545, U.S.A.
}

(Received 20th October 1973)

Evidence has accumulated that insertion of a foreign body into the uterine lumen (Spilman \& Duby, 1972; Wilson, Cenedella, Butcher \& Inskeep, 1972; Chaudhuri, 1973; Saksena \& Harper, 1974; Saksena, Lau \& Castracane, 1974) or its distension (Poyser, Horton, Thompson \& Los, 1971) induces a significantly greater production of prostaglandin (PG) than in control uteri in several species including man (Batta, Mukerjee \& Santhakumari, 1972). Likewise, the elevated levels of PG in the presence of an IUD and its effect on luteal regression (Spilman \& Duby, 1972) and the antifertility effect induced by an IUD has been successfully reversed in rabbits by administering indomethacin (Saksena \& Harper, 1974), an inhibitor of prostaglandin biosynthesis (Vane, 1971). All this evidence suggests that prostaglandins are involved in the mechanism of action of an IUD. We reported a preimplantation rise of uterine prostaglandin $\mathrm{F}$ (PGF) content and concentration in rabbits, rats and hamsters bearing IUDs (Saksena \& Harper, 1974; Saksena et al., 1974).

The aim of the present study was to determine whether the contraceptive action of an IUD in mice is a result of the release of prostaglandins and whether indomethacin could block the increase in prostaglandin production in the uterine tissue after insertion of an IUD.

Mature female mice (Charles River, CD-1) weighing 23 to $28 \mathrm{~g}$ were housed under controlled environmental conditions of light $(14 \mathrm{hr})$ and temperature $\left(23 \pm 1^{\circ} \mathrm{C}\right.$ ). Under pentobarbital sodium anaesthesia, two pieces of silk thread (Deknatel Surgical, No. 6-0) were inserted along the entire length of both the uterine horns by piercing the uterine wall and were secured by tying the free ends together. Two weeks after insertion of bilateral IUDs, the females were paired with males of proven fertility on the day of pro-oestrus. The presence of a vaginal plug was taken to indicate successful mating and the day on which one was found was termed Day 1 of pregnancy. Other groups of untreated normal females were mated and served as controls. All animals were killed by cervical dislocation and the uterine horns were cleaned; threads were removed from the uterine horns of experimental animals and uteri were frozen on dry ice, weighed separately and stored at $-15^{\circ} \mathrm{C}$ until required. The day and time of uterine sample collections are indicated in Tables 1 and 2.

Frozen uterine samples were homogenized in glass homogenizers in cold acetate buffer $(\mathrm{pH} 4 \cdot 5)$ to which $\left[{ }^{3} \mathrm{H}\right] \mathrm{PGF}_{2 \alpha}(\sim 1500 \mathrm{~d} / \mathrm{min})$ was added for the calculation of recovery losses. Extraction was carried out with two 10-ml 
vols of ethyl acetate by a method described by Skarnes \& Harper (1972). The pooled ethyl acetate was washed with $5 \mathrm{ml}$ distilled water, dried under nitrogen and chromatographed (Caldwell, Burstein, Brock \& Speroff, 1971). The fractions containing PGF were assayed in duplicate by a double antibody radioimmunoassay (Stylos, Burstein, Rivetz, Gunsalus \& Skarnes, 1972). Prostaglandins $F_{1 \alpha}$ and $F_{2 \alpha}$ are not distinguishable by this procedure so that results were expressed as total PGF. All the samples were analysed in one assay and the water blanks did not exceed $50 \mathrm{pg}$. Another six pregnant animals (Table 2) were treated with indomethacin ( $200 \mu \mathrm{g} /$ animal, subcutaneously) at

Table 1. Uterine weight and PGF content in normal and IUD-bearing pregnant mice

\begin{tabular}{|c|c|c|c|c|}
\hline \multirow{2}{*}{$\begin{array}{l}\text { Day of pregnancy } \dagger \\
\text { and time of sample } \\
\text { collection (hours) }\end{array}$} & \multicolumn{2}{|c|}{ Mean uterine weight $\pm S . E$. ( $(m g)$} & \multicolumn{2}{|c|}{$\begin{array}{c}\text { Mean uterine PGF content } \\
\pm S . E . \text { (ng/organ) }\end{array}$} \\
\hline & Control & $I U D$ & Control & $I U D$ \\
\hline $\begin{array}{l}\text { Day } 3: 22.30 \text { to } 23.00 \\
\text { Day } 4: 08.30 \text { to } 09.00 \\
\text { Day } 4: 15.30 \text { to } 16.00 \\
\text { Day } 4: 22.30 \text { to } 23.00 \\
\text { Day 5: } 08.30 \text { to } 09.00\end{array}$ & $\begin{array}{r}78.7 \pm 6.0(6) \\
120 \cdot 8 \pm 10.9(6) \\
111 \cdot 7 \pm 12 \cdot 8(6) \\
118 \cdot 3 \pm 7.0(6) \\
131.5 \pm 6.9(6)\end{array}$ & $\begin{array}{l}160 \cdot 0 \pm 14 \cdot 6^{* *}(7) \\
179 \cdot 0 \pm 10 \cdot 2^{*} \quad(6) \\
188 \cdot 3 \pm 22 \cdot 1 * \quad(6) \\
204 \cdot 5 \pm 8 \cdot 5^{* *}(6) \\
230 \cdot 8 \pm 22 \cdot 5^{* *}(6)\end{array}$ & $\begin{array}{l}3 \cdot 2 \pm 0 \cdot 4 \\
3 \cdot 0 \pm 0 \cdot 7 \\
4 \cdot 0 \pm 1 \cdot 0 \\
3 \cdot 2 \pm 0 \cdot 4 \\
2 \cdot 5 \pm 0 \cdot 6\end{array}$ & $\begin{array}{l}15 \cdot 5 \pm 1 \cdot 5^{* *} \\
18 \cdot 0 \pm 2 \cdot 0^{* *} \\
13 \cdot 4 \pm 1 \cdot 3^{* *} \\
13 \cdot 6 \pm 3 \cdot 2 * * \\
12 \cdot 1 \pm 3 \cdot 1^{* *}\end{array}$ \\
\hline
\end{tabular}

Figures in parentheses show the number of animals used.

* Differ significantly from their respective controls at $P<0.05$ ( $t$ test).

** Differ significantly from their respective controls at $P<0.01$ ( $t$ test).

$\uparrow$ Day $1=$ the day on which a vaginal plug was found.

Table 2. Effect of indomethacin on uterine weight and uterine PGF content in IUD-bearing pregnant mice

\begin{tabular}{c|c|c}
\hline \multicolumn{1}{c|}{ Treatment } & $\begin{array}{c}\text { Mean uterine weight } \pm \text { S.E. } \\
(\mathrm{mg})\end{array}$ & $\begin{array}{c}\text { Mean uterine PGF content } \pm \text { S.E. } \\
(\mathrm{ng} / \text { organ })\end{array}$ \\
\hline IUD only (controls) & $179 \cdot 0 \pm 10 \cdot 2(6)$ & $18 \cdot 0 \pm 2 \cdot 0$ \\
IUD+ Indomethacin $\dagger$ & $185 \cdot 8 \pm 9 \cdot 8(6)$ & $0 \cdot 1^{* *}$ \\
\hline
\end{tabular}

Figures in parentheses show the number of animals used.

** Differ significantly from their respective IUD-bearing controls at $P<0.01$.

$\dagger$ Indomethacin was injected subcutaneously at 04.30 hours and samples were collected between 08.30 and 09.00 hours on Day 4 of pregnancy.

04.30 hours on Day 4 of pregnancy in order to block the elevated levels of PGF obtained on Day 4 between 08.30 and 09.00 hours. Indomethacin was also injected once a day ( 30 and $75 \mu \mathrm{g} /$ day on Days 2, 3 and 4 of pregnancy) into bilateral IUD-bearing pregnant mice in an attempt to reverse the contraceptive action. The significance of differences was calculated by Student's $t$ test.

It can be seen from Table 1 that in the presence of bilateral IUDs the uterine weight was significantly increased compared to that in untreated pregnant mice. A significant increase in uterine PGF content and concentration was also recorded in 3-day pregnant animals with bilateral IUDs. The peak value was 
obtained on Day 4 of pregnancy between 08.30 and 09.00 hours (Table 1). The PGF content and concentration decreased gradually towards Day 5 of pregnancy, but a significantly greater uterine content and concentration was found than that recorded in the control mice. Indomethacin treatment at 04.30 hours on Day 4 of pregnancy abolished this increase (Table 2) in uterine PGF content and concentration of mice with bilateral IUDs. Treatment with indomethacin at 30 and $75 \mu \mathrm{g} /$ day/mouse, however, failed to reverse the contraceptive action of bilateral IUDs in both groups, each of which contained seven mice. The conception rate in our mouse colony is about $95 \%$.

In mice, bilateral sterilization by a thread inserted in one horn of the uterus is well documented (Doyle \& Margolis, 1966; Bartke, 1968). Marston \& Kelly (1969) suggested that a unilateral IUD could cause extensive infiltration of leucocytes into both horns and thus prevent the occurrence of pregnancy. In the present study in which ten mice were used to check the effectiveness of a unilateral IUD, there were no implantation sites in either uterine horn. This confirms the earlier findings of Doyle \& Margolis (1966). It was suggested (Doyle \& Margolis, 1966) that an IUD acts by altering either the ovum transport or by causing abnormal endometrial secretions. Recent reports (Chaudhuri, 1973; Saksena \& Harper, 1974; Saksena et al., 1974; Spilman \& Duby, 1972) suggest that an IUD may act through a local release of PG in the uterine lumen of rabbits, rats, hamsters and sheep. It is possible that this release results from an infiltration of leucocytes or from local inflammation (Greenwald, 1965).

The results of the present study clearly indicate that insertion of an IUD in mice stimulates release of PGF into the uterine lumen around the time of implantation. Moreover, the observations that uterine hypertrophy occurs in the presence of an IUD agrees with the findings in the rat of Parr \& Segal (1966). It was also been suggested that an IUD may produce an oestrogen-like effect in the uterus (Kar, Goswami, Kamboj \& Chowdhury, 1964). Oestrogens have been shown to cause increased uterine production of PG in several species (Blatchley, Donovan, Poyser, Horton, Thompson \& Los, 1971; Blatchley, Donovan, Horton \& Poyser, 1972; Saksena \& Harper, 1972; Saksena \& Lau, 1973). It seems that in this study the elevated PGF content and concentration in the uterine tissue around the time of implantation resulted from increased oestrogen uptake as proposed by Wrenn, Wood \& Bitman (1969) and Labhsetwar \& Perser (1972). Skarnes \& Harper (1972) demonstrated in mice that indomethacin inhibits PG synthesis in vivo. The present experiments also show an effect of indomethacin in vivo in mice. The IUD-induced increase in PGF levels in the uterine tissue was significantly inhibited when a single subcutaneous injection of $200 \mu \mathrm{g}$ indomethacin was given at 04.30 hours and animals were killed between 08.30 and 09.00 hours on Day 4 of pregnancy.

Our results support the concept that, after the insertion of an IUD, large amounts of PG are synthesized and released into the uterine lumen, and that this may interfere with implantation processes. Another possibility might be that an IUD exerts its effect by interfering with the secretion of progesterone from the ovary by a counter-current distribution mechanism, as suggested earlier in our studies with rats (Saksena et al., 1974). 
Grateful thanks are due to Dr W. Stylos for PGF antiserum. This study was supported in part from Institutional Funds of Worcester Foundation for Experimental Biology, Ford Foundation and from an A.I.D. contract $(\operatorname{csd} / 2837)$.

\section{REFERENCES}

BARTKE, A. (1968) Effect of an IUD on implantation and decidual reaction in different strains of mice. F. Reprod. Fert. 15, 185.

Batta, S. K., Mukerjee, B. \& Santhakumari, G. (1972) Pharmacological studies on the uterine flushing in women with and without intrauterine devices. Archs int. Pharmacodyn. Therr. 196, 174.

Blatchley, F. R., Donovan, B. T., Horton, E. W. \& Poyser, N. L. (1972) The release of prostaglandins and progestin into the utero-ovarian venous blood of guinea pigs during the oestrous cycle and following oestrogen treatment. 7. Physiol., Lond. 223, 69.

Blatchley, F. R., Donovan, B. T., Poyser, N. L., Horton, E. W., Thompson, G. J. \& Los, M. (1971) Identification of prostaglandin $F_{2 \alpha}$ in the utero-ovarian blood of guinea pigs after treatment with oestrogen. Nature, Lond. 230, 243.

Galdweli, B. V., Burstein, S., Brock, W. A. \& Speroff, L. (1971) Radioimmunoassay of F-prostaglandins. F. clin. Endocr. 33, 171.

Ghaudhuri, G. (1973) Release of prostaglandins by the IUCD. Prostaglandins, 3, 773.

Doyle, L. L. \& MARGolis, A. J. (1966) The effect of an IUFB on reproduction in mice. J. Reprod. Fert. $11,27$.

Greenwald, G. S. (1965) Interruption of pregnancy in the rat by a uterine suture. F. Reprod. Fert. 9, 9.

Kar, A. B., Goswami, A., KamboJ, V. P. \& Ghowdhury, S. R. (1964) Effect of foreign body on the response of the uterus of ovariectomized rats to estrogen. Steroids, 4, 159.

Labhsetwar, A. P. \& Perser, N. (1972) Uterine uptake of $\left[6,7-{ }^{3} \mathrm{H}\right]$ oestradiol in the presence of intrauterine contraceptive device in cyclic and pregnant rats. Acta endocr., Copenh. 69, 583.

Marston, J. H. \& Kelly, W. A. (1969) The time and site of contraceptive action of an intrauterine device in mouse. J. Endocr. 43, 83.

PARR, E. L. \& SEGAL, S. J. (1966) The effect of an intrauterine contraceptive device on the weight of the rat uterus. Fert. Steril. 17, 648.

Poyser, N. L., Horton, E. W., Thompson, G. J. \& Los, M. (1971) Identification of PGF $2 \alpha$ released by distension of guinea pig uterus in vitro. Nature, Lond. 230, 526.

SAKsena, S. K. \& HARPER, M. J. K. (1972) Levels of F-prostaglandin (PGF) in uterine tissue during the estrous cycle of hamster: effect of estradiol and progesterone. Prostaglandins, 2, 405.

Saksena, S. K. \& Harper, M. J. K. (1974) Prostaglandin mediated action of IUDs. I. F-prostaglandins (PGF) in the uterine horns of pregnant rabbits with a unilateral intra-uterine device. Fert. Steril. 25, 121.

Saksena, S. K. \& LAU, I. F. (1973) Effect of exogenous estradiol and progesterone on the uterine tissue levels of prostaglandin $\mathrm{F}_{2 \alpha}\left(\mathrm{PGF}_{2 \alpha}\right)$ in ovariectomized mice. Prostaglandins, $3,317$.

Saksena, S. K., Lau, I. F. \& Castracane, V. D. (1974) Prostaglandin mediated action of IUDs. II. F-prostaglandins (PGF) in the uterine horn of pregnant rats and hamsters with intra-uterine devices. Prostaglandins, 5, 97.

Skarnes, R. G. \& Harper, M. J. K. (1972) Relationship between endotoxin-induced abortion and the synthesis of prostaglandin F. Prostaglandins, $1,191$.

Spilman, G. H. \& Duby, R. T. (1972) Prostaglandin-mediated luteolytic effect of an intrauterine device in sheep. Prostaglandins, 2, 159.

Stylos, W., Burstein, S., Rivetz, B., Gunsalus, P. \& Skarnes, R. G. (1972) The production of antiF-prostaglandin serum and its use in radioimmunoassay. Intra-Sci.chem. Rep. 6, 67.

VANE, J. R. (1971) Inhibition of prostaglandin synthesis as a mechanism of action for aspirin-like drugs. Nature, New Biology, 231, 232.

Wilson, L., JR, Cenedella, R. J., Butcher, R. L. \& Inskeep, E. K. (1972) Levels of prostaglandins in the uterine endometrium during the ovine estrous cycle. F. Anim. Sci. 34, 93.

WRENN, T. R., WOOD, J. R. \& BITMAN, J. (1969) IUDs and the biochemical responses of the uterus to estrogen in ovariectomized rats. Biol. Reprod. 1, 234. 